\title{
What Drives China's New Agricultural Subsidies?
}

\section{Introduction}

Following market reforms three decades ago, China's agricultural policy has undergone a fundamental transformation and now involves a wide array of policy instruments that range from output and input subsidies to public infrastructure expenditures. Chinese agricultural policies underwent a fundamental shift from farm taxation, typical of developing countries, to farm subsidies and direct payments more typical of developed countries. ${ }^{i}$ Because the People's Republic of China is the world's largest importer, producer, and consumer of agricultural products, its policy changes have significant impact on world markets, including developing countries that rely on agricultural trade for export revenues or on imports of agricultural staples to ensure food security. This highlights the need to better understand the drivers of policy changes in China.

After its establishment in 1949, the new Chinese regime adopted a Soviet-style, heavy industry-oriented development strategy as its main economic objective. Until 1978, agricultural production was organized into cooperatives and people's communes, a form of supracooperative (Lin, 1990; Party History Research Center of the CPC Central Committee of China, 2011), with the government generally procuring commodities at below-market prices via state monopsonies to subsidize urban consumption and industrial development (Carter et al., 2002). As urban residents' incomes and industrial production subsequently increased, widespread urban food subsidies became less necessary amid increasing concerns about the widening gap between rural and urban incomes and insufficient investments in agriculture. These factors 
induced a shift towards supporting rather than taxing farmers. Between 1989 and 1994, there was a period of relative instability in China that coincided with the Tiananmen Square incident, with the central government paying renewed attention to urban interests. In 1994, the government resumed its policy of maintaining and stabilizing producer prices through procurement and trade policy for important commodities, such as wheat, soybeans, and corn, at prices substantially above international levels (Fang, Tuan and Zhong, 2002). Given the financial burden they imposed, these measures were replaced by selective support payments that were not directly linked to prices (Xiao, 2005; Zheng et al, 2013).

In December 2001, China joined the World Trade Organization (WTO), and, in 2006, the central government abolished agricultural taxes and introduced direct income subsidies. In order to control for price volatility and to further protect farmers, China also introduced a minimum price policy via a non-recourse loan program. ${ }^{\text {ii }}$ A comprehensive program to subsidize agricultural inputs also began in 2006, with agricultural machinery subsidies from 2008 onwards. These two mechanisms now constitute the main support for agriculture provided through budgetary transfers. In compliance with WTO rules, China applies tariff-rate quotas to wheat, rice, corn, sugar, wool, cotton, and some fertilizers to limit quantities over a quota rate. China also maintains a variety of non-tariff barriers that include import licenses, state trading, and food safety measures (Carter and Rozelle, 2002).

The main contribution of this paper is to quantitatively investigate the determinants of the levels of agricultural subsidies in China over the last three decades, using a political-economic model to explain the levels of agricultural producer subsidies, with particular attention to 
emerging agricultural policy changes. While there is a large body of literature that investigates the determinants of agricultural protection in other countries (e.g., Gawande and Hoekman, 2006; Klomp and de Haan, 2013), as well as numerous studies on the impacts of the new agricultural policies in China (e.g., Yu and Jensen, 2010; Wang and Shen, 2014), there is a lack of studies that quantitatively analyze the drivers of these policy changes in China.

We present a political-economic conceptual model that explains output and input subsidy decisions by government and conduct comparative statics to elicit empirical hypotheses. We then use 1984-2012 annual data for 16 commodities' producer subsidy equivalents (PSEs) in China to examine the drivers of PSE changes in this period. Empirical results indicate that national factors, such as economic growth and a declining share of agriculture in the economy, have been the primary factors. In essence, China's agricultural policies now resemble those of developed counties due to economic transformation and the ability to restructure and reinforce agricultural policies within the WTO rules.

\section{Trends in Production, Consumption and Subsidies}

\subsection{Trends in Production, Consumption and Imports}

Although China remains a developing country and its per capita income is still a fraction of those in advanced countries (World Bank, 2015), its transition from a "low-income" developing country to a "high-income" one it is undeniable. A number of recent studies highlight the rise of income as the major driving force leading to an increase in food consumption, particularly of meat products (Huang, Rozelle, and Rosegrant 1998; Ma et al. 2004; Fuller et al. 2000; Zhou 
and Tian 2003; Zhou et al. 2012).

To further examine the trends in food production and consumption in the last decades, we examine the top four agricultural commodities in terms of the farm value of sales in China, between 1990 and 2010. This group of key commodities includes four animal products (pork, poultry, beef and milk products) and four crops (rice, wheat, corn, and soybeans). The trends in agricultural production, consumption and imports on a per capita basis are shown in Figures 1 and 2. As expected, per capita consumption increased between 1990 and 2010 for all the commodities in question, except for rice, which experienced a modest decline in the diet of the average Chinese consumer.

For meat products, as shown in Table 1, the increases in per capita consumption are dramatic. For instance, while the per capita consumption of pork (the commodity with the largest share of per capita consumption) nearly doubled between 1990 and 2010, the per capita consumption of poultry, milk products, and beef increased between five and six times. In fact, in general, the consumption of livestock products experienced the strongest steady growth in China, which follows the growth of income, which not only allows for an increase in total consumption but for diversification and improvement in the diet. Starting from a few inexpensive starchy staples like rice and noodles, thanks to the increase in income, consumers increased the consumption of more expensive foods, such as meat or processed foods. ${ }^{\text {ii }}$ It is also interesting to note that the increases in consumption have been nearly matched by increases in production on a per capita basis. This means that China has been successful in expanding agricultural production to meet its domestic requirements for animal products in the diet. 
For crops, as shown in Table 2, it is interesting to note that while corn and soybeans experienced a significant increase in per capita consumption (nearly 50\% and 500\%, respectively, in the period in question), per capita consumption of rice and wheat declined modestly. However, as most of the corn crop is devoted to feed, the increase in corn consumption reflects both direct consumption and derived demand through livestock feed purposes. Moreover, approximately $75 \%$ of soybeans in 2010 were purchased for further processing by the agro-food complex (FAO 2015), also reflecting both direct consumption but mainly an expansion of a derived demand through food processing purposes. Thus, much of the pool in key crop commodities whose consumption is expanding, like corn and soybeans, is a result of push from feed and food processing purposes. Along with the trends in meat consumption and grains for direct consumption, Table 1 clearly supports the notion that China is experiencing the transition of increasing consumption of animal products while decreasing consumption of starchy staples. It is interestng to note that unlike other commodities, the production of soybeans has mainly held steady, with increases in consumption being met primarily through imports.

The trends in production and consumption are also dependent in part on international trade, particularly for imports. The per capita volume of imports is shown on the right axis of Tables 1 and 2. In fact, the economic transformation of China constitutes an important export opportunity for the rest of the world, as Chinese dietary changes are likely to continue. China's self-sufficiency concerns initially involved mostly grains, but, nowadays, China is almost completely independent from foreign imports, as reflected by import penetration, whereas 
foreign dependence seems to be increasing for animal products. Yet, as reflected by low import penetration, the difference between domestic consumption and domestic production, still remains relatively small (with the exception of soybeans), reaching a maximum of approximately $10 \%$ of consumption for poultry and milk products in 2010 and remaining negligible for pork and rice, where it stayed well under $2 \%$ and $1 \%$ of per capita consumption, respectively. Finally, it is interesting to note that while poultry imports have increased only modestly to meet demand, pork imports have not: pork production increases have closely paralleled the increase in consumption, so very little dependence on imports has been needed. To sum up, in spite of dramatic increases in consumption of meat products, China has managed to meet nearly all of its domestic requirements by expanding internal production.

\subsection{Changes in the Structure of Agricultural Subsidies}

As Huang, Wang and Rozelle (2013) point out, the rise of subsidies directed to farm households appeared in a noticeable way for the first time in the early 2000s. Since then, Chinese agricultural policies have changed dramatically in the magnitude and nature of payments. For instance, Huang, Wang, and Rozelle (2013) examine grain, input, seed and machinery subsidy programs and conclude that China has been following the path from taxes to subsidies since the early 2000 s.

To provide further insight into the structure of agricultural subsidies in China, we rely on producer subsidy equivalents (PSEs), which measure the value of agricultural subsidies as a percentage of the value of production at the farm level, including output and input price policies as well as direct payments. PSEs have the advantage of providing a comprehensive account of 
multiple input and output policies, not only through payments (as in Huang, Wang and Rozelle, 2013) but also through market mechanisms and for agricultural commodities other than grains, including non-grain crops and livestock products. The PSE measure only includes price policies and transfers that target farmers' individual commodity sectors as well as the agricultural sector as a whole. It does not include other policies that create more favorable conditions for the Chinese farmers, such as support for the agro-processing industry, economywide development of infrastructure, subsidies for rural health and education, and rural pension systems (OECD, 2014b).

Figure 3 presents the PSEs by input v. output subsidies in the 1984-2012 period. Throughout the period, input subsidies were positive but increased significantly since 2000 . This is consistent with a cheap food policy that lowers the cost of production and shifts supply, resulting by itself in below free market prices. The trend in output subsidies that tax consumers rather than subsidizing producers went from negative before 2000 to positive after 2000 ; i.e., input and output policies favored consumers before 2000 by inducing below free-market agricultural commodity prices. It is interesting to note that particularly during the 1989 Tiananmen Square incident and the subsequent three years, relatively large transfers occurred from producers to consumers via negative output PSEs that far outweighed modest input subsidies. However, after 2000, producers received large transfers through increased input subsidies as well as supra-competitive agricultural commodity prices that taxed consumers rather than producers, particularly after 2001 when China entered the WTO.

Figure 4 illustrates a decomposition of PSEs by crops v. livestock products. Although 
crops were generally supported at a significantly higher level prior to 1995, the levels of support are more similar after that. Thus, although both categories of PSEs increased over the sample period (with the exception of the period of Tiananmen Square and the three following years), livestock product support has increased relatively more since 1984.

In sum, to characterize the structure of agricultural subsidies during the 1984-2012 period, (1) central government budget transfers in this period have always been positive, aimed particularly at inputs, and have increased substantially since 2000; and (2) consumers were subsidized through output policies up to 2000 but are now instead subsidizing agricultural producers through the new output policies. Whether or not the new changes in policies are due to external factors, such as joining the WTO in 2001, or are a result of economic transformation or commodity-specific factors needs to be analyzed within an integrated framework that takes these factors into account.

\section{Conceptual Framework}

This section focuses on the conceptual determinants of output and input subsidies for a particular agricultural commodity market to articulate some hypotheses to be tested empirically. Following Lopez and Hathie (2000), we consider a model where the central government behaves as though it maximizes the weighted average of the welfare of various interest groups and whose objective function $(\mathrm{U})$ can be specified as:

$$
\operatorname{Max} U=C S+\theta P S+R
$$

where $C S$ is consumer surplus, $P S$ is producer surplus, $R$ is government rents generated from 
sector-specific intervention, and $\theta$ is the relative political weight assigned to producers of the agricultural commodity in question. Let $P S$ and $C S$ be defined by

$$
\begin{gathered}
P S=\int_{a}^{p} f(P, W) d p \\
C S=\int_{p}^{b} g(P) d p
\end{gathered}
$$

where the supply function of producers is denoted by $Q^{S}=f(P, W) . P$ is the price received by producers, and $W$ is an input price. The demand of domestic consumers is denoted by $Q^{d}=g(P)$. As usual, $f_{1}, f_{2}>0, g_{1}<0$, and $a$ and $b$ represent threshold levels of supply and demand prices (where $Q^{s}=0$ or $Q^{d} \rightarrow 0$ ), and other notation is as defined before modifying the model of Lopez and Hathie (2000). Government rents (R) are defined as

$$
R=\left(P-P_{w}\right)\left(Q^{d}-Q^{s}\right)-\left(W^{w}-W\right) X
$$

where $P_{w}$ and $W^{w}$ are border prices (at the official exchange rate), $X$ is the quantity of input subject to subsidy, and other notation is as defined before. Thus, if $P>P_{w}$ but still $Q^{d}>Q^{s}$ (the commodity is imported), then the government retains the positive price differential times the volume of imports. Likewise, if farmers pay $W<W^{W}$, the input purchases are subsidized.

To derive the conceptual government decision rules with respect to $P$ and $W$, take the first-order conditions for the maximization of (1) to obtain:

$$
\begin{aligned}
& \rho=\frac{\left(P-P_{w}\right) Q}{P Q}=\frac{P-P_{w}}{P}=\frac{\theta-1}{\eta \frac{Q^{d}}{Q^{S}}+\varepsilon} \\
& \tau=\frac{\left(W^{w}-W\right) X}{P Q}=\frac{1}{\gamma}\left(\frac{\theta \beta}{\varepsilon}-\frac{P-P_{w}}{P} \beta+\frac{X}{P Q}\right)
\end{aligned}
$$

where $\rho$ denotes the rate of output subsidy rate to producers, $\tau$ denotes the rate of input subsidy to producers, $\eta$ denotes the absolute value of the price elasticity of demand, and $\beta$ and $\varepsilon$ 
denote the elasticity of output supply with respect to input price and output price, respectively. $\gamma$ denotes the input supply elasticity with respect to input price, and $\kappa=\frac{Q^{d}}{Q^{s}}$ is the ratio of domestic consumption to domestic production. The latter can also be interpreted as an index of the extent to which domestic requirements are met by domestic production. Thus, $\kappa>1$ for imported commodities and $\kappa<1$ for exported ones. Thus self-sufficiency is inversely related to $k$.

By aggregating output subsidy rate and input subsidy rate, we obtain

$$
\Pi=\rho+\tau=\frac{\beta \theta}{\gamma \varepsilon}+\left(1-\frac{\beta}{\gamma}\right) \frac{\theta-1}{\eta \kappa+\varepsilon}+\frac{X}{\gamma P Q}
$$

Taking the first order derivatives of $\Pi$ with respect to $\theta, \varepsilon, \eta, \beta, \gamma$ and $k$ one obtains:

$$
\begin{aligned}
& \frac{\partial \Pi}{\partial \theta}=\frac{\beta}{\gamma \varepsilon}+\left(1-\frac{\beta}{\gamma}\right) /(\eta k+\varepsilon)>0, \\
& \frac{\partial \Pi}{\partial \varepsilon}, \frac{\partial \Pi}{\partial \eta}= \begin{cases}<0 & \text { if } \theta>1 \\
>0 & \text { if } \theta<1\end{cases} \\
& \frac{\partial \Pi}{\partial \gamma}>0 \\
& \frac{\partial \Pi}{\partial \kappa}<0 .
\end{aligned}
$$

Based on the comparative statics analysis above, four hypotheses are proposed for Chinese agricultural subsidies:

Hypothesis 1: Producer subsidy rates increase as relative political weight assigned to producers increases (based on 8.1);

Hypothesis 2: Producer subsidy rates increase (decrease) as the price elasticities of output supply or demand increase (decrease) if producers have more (less) political power than consumers (based on 8.2); 
Hypothesis 3: Producer subsidy rates increase as supply elasticity with respect to input price increases (based on 8.3);

Hypothesis 4: Producer subsidy rates decrease as self-sufficiency of an agricultural commodity increases (based on 8.4);

The intuition behind hypothesis 1 is supported by the experience of developed countries because farmers receive higher subsidy rates as the non-farm economy develops. The intuition behind hypothesis 2 follows from the effectiveness of price subsidies to support farmers as the

price elasticity of supply increases. ${ }^{\text {iv }}$ We do not have an intuitive explanation for the positive relationship between $\Pi$ and $\eta$ when producers have a greater political weight than consumers, and we leave this to empirical testing. Hypothesis 3 is supported by the effectiveness of input subsidies in stimulating production, as the price elasticity of supply increases with decreasing input prices. Hypothesis 4 makes sense as the pressure to subsidize consumers increases as the supply of food staples becomes more dependent on imports. From Figure 1, this is more clearly the case for animal products, as the diet transformation towards high protein has pushed imports and consumption relatively more than for crop commodities. Hypothesis 1 cannot be directly empirically tested since $\theta$ is not observed, but its hypothesized covariates are, so the effect of the covariates on agricultural PSEs can be tested. Hypotheses 2-4 are directly empirically tested with data, as discussed below.

\section{Empirical Model and Data}

Following previous work (e.g., Honma and Hayami, 1986; Beghin and Kherallah, 1994; 
Lopez and Hathie, 2000), we specify an equation model to explain the levels of subsidies at the commodity level based on equation (7), using PSEs as a proxy for П. The next task is to identify the elements in the explanatory variables of (7) underlying $\theta, \eta, \varepsilon, \beta, \gamma$, and $\kappa$ to explain changes in PSEs. We treat the first as determined by the national political agenda, i.e., beyond single commodity markets, and the second to sixth as commodity specific drivers.

First, we discuss exogenous shifters of $\theta$ stemming from the national political agenda. Accordingly, one can reasonably expect that per capita real GDP (GDPC) will be positively correlated with PSE. Since 1978, China's GDP has shown an average annual growth of almost $8 \%$ and a substantially decreased level of poverty, although the rate of decrease has slowed in the last few years. This variable is often encountered in studies of agricultural protection and is used as a proxy for a country's stage of development (Beghin and Kherallah, 1994). The rationale for its use is that a rise in per capita income reduces the financial burden of agricultural protection on the non-agricultural population, thereby reducing resistance to protectionism or subsidization of inputs. Higher agricultural prices become more tolerable to consumers as their incomes rise, and thus one expects a positive relationship between PSE and real GDP per capita. That is, the political weight assigned to agricultural producers in China is expected to rise with national economic growth.

As in Honma and Hayami (1986), another explanatory variable expected to change $\theta$ is the share of agriculture in the gross domestic product (Agshare), which is a measure of the importance of agriculture in the national economy. Previous studies have found a negative relationship between this variable and the level of protection (Honma and Hayami, 1986; Lopez 
and Hathie, 2000). The hypothesis is that the more important agriculture is in the economy, the more politically effective it will be to tax it and the more politically costly to subsidize it, suggesting a negative sign between this variable and PSE. In fact, this provides an explanation for the initial taxation of Chinese agriculture in the immediate period following 1949. Other national level control variables that are hypothesized to shift $\theta$ include dummy variables for alternative policy periods discussed above. Accordingly, one expects a negative effect of the 1990-94 period on PSE and a positive effect of the post-WTO period.

To investigate the impact of China's entry into the WTO, we divide the total time span, 1984-2012, into two different time periods: (1) the benchmark period 1984-2001, accounting separately for the urban instability period from 1990 to 1994, following the Tiananmen Square incident; and (2) the WTO period from 2002 to 2012. A trend variable (Trend) is added throughout the period to pick up long term trends not explained by other factors.

Next, we discuss explanatory variables that are commodity-specific. From the conceptual model, three commodity-specific variables are the supply and demand elasticities, and supply elasticity with respect to input price $(\varepsilon, \eta$ and $\beta)$, which were estimated for each year for each commodity in the sample. Supply elasticity is hypothesized to have a positive effect on PSEs, while demand elasticity is expected to have an indeterminate effect on PSEs as per the conceptual analysis presented above, and supply elasticity with respect to price is expected to have a positive impact on PSEs. Because no comprehensive supply and demand elasticities statistics are available, this paper uses simple two-stage least squares regression to compute supply elasticities for each year. Demand elasticities are based on a linear model 
and previously published elasticities by the USDA (2006). ${ }^{v}$ The input supply elasticity with respect to input price $\gamma$ is not inlcuded in the model due to data limitations. We measure $\kappa$ as the ratio of domestic consumption to domestic $\left(\kappa=\frac{Q^{d}}{Q^{s}}\right)$, as suggested in the theoretical analysis, providing an index of the inverse of self-sufficiency with respect to each commodity (Self-insufficiency). An index of 1 implies full self-sufficiency and no imports, while an index greater than 1 implies increasing reliance on imports to meet domestic consumption. In the case of China, the export of agricultural commodities in the sample does not appear to be of significant magnitude to affect the interpretation of our index. The data for quantities of consumption and production for each commodity came from the USDA (1994) and OECD (2014b).

Moreover, we also include other commodity-specific control variables that seem relevant in the Chinese political economy environment. One variable found in discussions in the general political economic literature is the geographic dispersion and size of industries. To this end, an explanatory variable for political bargaining power is measured by the geographic concentration of production (GEOG). ${ }^{\mathrm{vi}}$ We adopt the concept of the "lobbying power" function (Magee, Brock, and Young, 1989), where what matters is the interaction of industry concentration and sales. The first is expected to reduce organizing costs and the second is the size of the jackpot for a given subsidy or protection level. Thus, one would expect a positive relationship between this variable and PSE.

Finally, we also include the lagged PSE for each commodity to account for institutional lags that affect the timing of policy changes. As with other government policies, Chinese 
agricultural policies are set before they become effective and are thus based on lagged economic and political information. The inclusion of lagged PSE in the model is theoretically valid considering that current PSE levels are heavily determined by their past levels. If lagged PSEs are statistically significant, reflecting partial adjustment behavior in the short run, then the longrun effects of covariates are significantly larger than the estimated coefficients.

Following the stylized facts and explanatory variables discussed above, we specify a simple equation to explain PSEs of commodities in China over the 1984-2012 period:

$$
\begin{aligned}
& \mathrm{PSE}_{\mathrm{jt}}=\alpha_{0}+\alpha_{1} \mathrm{GDPC}_{\mathrm{t}}+\alpha_{2} \text { Agshare }_{\mathrm{t}}+\alpha_{3} \varepsilon_{\mathrm{jt}}+\alpha_{4} \eta_{\mathrm{jt}}+\alpha_{5} \beta_{\mathrm{jt}}+\alpha_{6} \kappa_{\mathrm{jt}}+\alpha_{7} \mathrm{GEOG}_{\mathrm{jt}}+
\end{aligned}
$$

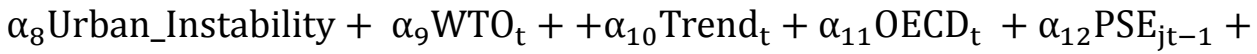

$$
\begin{aligned}
& \alpha_{13} \mathrm{FE}_{\mathrm{j}}+\mathrm{u}_{\mathrm{jt}}
\end{aligned}
$$

where $\mathrm{PSE}_{j t}$ is the percent of the value of production accounted for by output and input policy transfers for commodity $j$ in year $t$, and $u_{j t}$ is an error term. Considering that we combine PSE data from USDA for the 1984-1992 period (USDA, 1994) and OECD for1993-2012 (OECD 2014b), and that there might be a systematic difference between PSEs from the two different sources, we include a structural break dummy variable, $O E C D_{t}$, to capture the possible structural difference between measurements from the two sources. We also include a commodity fixed effects dummy variable, $F E_{j}$, in the model. Other independent variables are as defined above. To check for robustness with respect to the specification of our dependent variable, we run the same model specification using the Nominal Rate of Protection (NRP) instead of PSEs. ${ }^{\text {vii }}$ 
The data used to estimate the empirical model in (9) came from three main sources: (1) the data on PSE, NRP, domestic production and consumption for each commodity are from the USDA (1994) and OECD (2014b); (2) economy-wide variables were collected from various issues of the China Statistical Yearbook by the National Bureau of Statistics of China (19952013a); and (3) commodity-specific variables came from various issues of the China Rural Statistical Yearbook by the National Bureau of Statistics of China (1995-2013b) and the USDA's China Agricultural and Economic Data (1995-2013) (USDA, 2012). The combined database consists of annual observations from 1984 through 2012 for 16 agricultural commodities. ${ }^{\text {viii }}$ The final sample consists of unbalanced panel data for 16 commodities over 29 years.

Table 1 shows the summary statistics of variables for four policy periods in the sample. The average GDP per capita, adjusted for inflation, increased from 1,001 RMB in the first period to 20,520 RMB in the fourth period. Agriculture's share of the GDP decreased from 22\% to $10 \%$. The PSEs were the lowest during the second policy period, which included the Tiananmen Square incident and subsequent years. Average production levels and production values, as well as average consumption levels and values, increased yearly during the full period of analysis.

The concern about endogeneity in equation (9) was confirmed by the Sargan test. In addition, considering that lagged PSE is included as an independent variable and that subsidies can affect production levels and values that are components of certain explanatory variables, we use a Generalized Method of Moments (GMM) to deal with such potential endogeneity 
issues (Arellano \& Bond, 1991; Arellano \& Bover, 1995; Blundell \& Bond, 1998; Blundell \& Bond, 2000). In particular, we use a system GMM econometric estimation method that relies on two equations - the original equation in (9) as well as the transformed one that explains changes in the dependent variable. Following Roodman (2009), we estimate both equations together using GMM in the Stata module xtrabond2. The results are presented below.

\section{Empirical Results}

\subsection{Econometric Results}

The parameter estimation results for the determinants of PSEs are presented in Table 4. Although the AR (1) statistic fails to reject the hypothesis of no first-order correlation of the error terms, the AR (2) statistic suggests that there is no second-order correlation of the error terms. The Sargan-test indicates that the instruments are appropriate and strong.

The empirical results summarized in Table 3 indicate that PSEs in China are significantly driven by national-level or macroeconomic factors, such as GDP per capita and agriculture's share of the GDP. Since 1978, China's ever-expanding economy, with an average annual growth rate of $8 \%$, due almost entirely to the non-agricultural sector, has driven decisions to subsidize agricultural producers. To determine which variable contributed most to the regression, the beta coefficients attempt to use the effect of an equally likely change in the variable, using standard deviations as a measure of a typical change. ${ }^{\text {ix }}$ With agriculture's share of the GDP going from $30 \%$ in 1984 to under $10 \%$ by 2012 , it is not surprising that the beta coefficients identify this sector's share of the GDP as providing the largest contribution to 
explaining variations in PSEs during the sample period.

Among the commodity-specific variables, demand elasticity failed to show a statistically significant impact on PSEs. Its expected sign was indeterminate and this is in line with the results of static comparative analysis. As expected, agricultural commodities with higher output price elasticities of supply are subsidized at higher rates. Commodities with higher geographic concentration rates that belong to larger sectors are also more likely to be subsidized, which is also in line with the theoretical prediction. The results also show that there is a significant institutional lag in PSE decisions, as reflected by the statistically significant, albeit relatively low, coefficient $(0.28)$ of the lagged dependent variable. This reflects some friction in the adjustment of PSEs to desired levels, but that relatively little yearly adjustment takes place, meaning that the Chinese government is quick to make policy decisions in response to national and commodity factors. The price elasticities of supply with respect to input prices, demand with respect to output price, and the self-insufficiency indexes did not show a significant effect on PSE decisions. The latter would suggest that self-sufficiency concerns have becomes less of a driving force for subsidy decisions in the last few decades, at least at the aggregate level.

It is interesting to note that the period of urban instability following the events of Tiananmen Square, in 1989, shows a significant dip in agricultural PSEs in China, as expected. In that period, it appears that both greater attention and budgeting concerns were placed on urban interests than previously. In spite of this, the results also show a downward pressure on PSEs following China's joining the World Trade Organization. The WTO effect is positive 
and statistically significant, suggesting that China's entry into WTO increased the agriculture subsidy rate. In essence, China's PSE determinants resemble those of developed countries, as reflected by some of the same policies that are less dependent on trade and more reliant on direct payments. Not surprisingly, China's agricultural policies seem to be driven more by international agreements or sector-specific conditions.

Figure 5 depicts the average actual and predicted PSEs for 16 agricultural commodities in China during the 1984-2012 period. As the figure shows, except for the 1989-94 period, China has provided subsidies to its farmers and, in more recent periods, particularly following the period of accession to the WTO in December 2001, it has increased the use of transfers from the central government budget as well as from consumers via prices.

In Table 4 we present the results for estimating equation (9) using the nominal rates of protection instead of PSEs as the dependent variable. The estimated coefficients were similar in terms of signs but with more coefficients being statistically insignificant. This is not surprising, since the NRP is only a partial measure of support that reflects the gap between the domestic and the border price for output. Thus, it is not as comprehensive as the PSEs. NRPs do not account for direct payments mainly used for input subsidies, which became very important after 2000 .

It is interesting to note that even with NRPs as the dependent variable, the per capita GDP growth and accession to the WTO exhibit strongly positive and significant effects on the level of aggregate producer subsidies in Chinese agriculture. 
Table 5 presents the PSE results for crops vs. livestock products. These results reinforce the aggregate PSE results in Table 3 but provide a further insight into the political differential for these two groups. For instance, national-level variables (GDP per capita and share of agriculture in the GDP) play a more prominent and statistically significant role in supporting livestock producers than crop producers. Another interesting result is that the self-sufficiency index (production over consumption) is also more prominent for livestock producers than for crop producers. This is particularly important as imports have increasingly played a growing role in supplying major livestock products such as pork and poultry. It is also interesting to note that accession to the WTO did not appear to have an effect on livestock producers but is strongly associated with an increase in PSEs for crop producers. In part, this can be explained by the significant increase in agricultural input subsidies, particularly machinery and fertilizers, which focused more on crop than livestock farmers.

\subsection{Agricultural Subsidy Forecasts for 2013-2022}

Since PSEs are more comprehensive than NRPs, the estimated PSE model reported in Table 3 was deemed appropriate for simulation beyond 2012. To assess the tendency of future PSEs, we utilize the estimated parameters in Table 3 to forecast PSEs in the 2013-2022 period. This first required predicting the pertinent independent variables. To this end, using a simple linear trend regression model with the 2002-2012 observations, we predict output prices, quantity of production, GDP per capita, and the share of agriculture in the economy. Other variables, like geographical concentration rate, supply elasticity, demand elasticity, and selfsufficiency, are assumed to remain unchanged. The reason for this was to utilize data from 
only the post-WTO period. The predicted variables were then plugged into the model to estimate 2013-2022 average PSEs. ${ }^{\mathrm{x}}$ Note that this was done for each of the 16 commodities, and then the results were aggregated into a single PSE for each year. The results are presented in Figure 6.

Based on the model predictions, agricultural PSEs in China are expected to increase only modestly and to remain under $20 \%$ of the value of production. This means that less than $20 \%$ of farmers' revenues would come from policy transfers. This level is a bit below the current level of PSEs for these commodities in the United States in 2014 (OECD, 2014b). The main drivers of moderately higher rates of PSEs are the decreasing share of agriculture in China's GDP and further increases in GDP per capita. According to International Monetary Fund (2015), the predicted real GDP per capita growth rate for China will decrease to $6.3 \%$ in 2022 (the Organization for Economic Cooperation and Development (2014a) predicts a decrease to 5\%). Nevertheless, based on the linear trend model that we used for all explanatory variables from 2002 to 2012, real GDP per capita will increase by 2845 RMB per year (in 1978 values). This implies an average per capita GDP growth of approximately $5.5 \%$, which is between the IMF and the OECD predictions. In spite of a recent slowdown in the Chinese economy, both urbanization and GDP are expected to increase further, providing a political rationale for continuing to subsidize agriculture, ${ }^{\mathrm{xi}}$ though at much lower, if any, rates of increase.

The results in Figure 7 which break down the predictions for 2013-2022 for crops vs. livestock products, show that both PSEs are expected to experience flat and slightly modest declines in the coming decade but that subsidies for animal products are expected to remain at 
a much lower level. This is consistent with the push from consumers for a protein-rich diet that is increasingly based on livestock products.

\section{Concluding Remarks}

China's agriculture policy has undergone fundamental changes in the last decades. Concerned about national food self-sufficiency and rural household incomes, China changed its longstanding policy of taxing farm households and began instead to subsidize them. This transformation has been facilitated by a transformation of the economy and strong economic growth performance in the last three decades, particularly in the non-agricultural sector.

Using a political economy model that incorporates factors that are likely to impact policy changes and 1984-12 data for 16 agricultural commodity sectors, this paper examines the political and economic drivers of these changes. Empirical results indicate that agricultural subsidies are strongly driven by macroeconomic factors, including the share of agriculture in the gross domestic product and per capita GDP. GMM estimation results suggest that a $1 \%$ increase of GDP increases the PSE by $0.50 \%$, while a $1 \%$ decrease of the share of agricultural

production increases PSE by $0.64 \%$ (Table 3). In the last three decades, the strong growth of GDP and the non-agricultural sectors in China has resulted in an increase in subsidy support for agriculture. This structural transformation in agricultural policies in China conforms with the pattern experienced by other developed countries in the past: as agriculture plays a smaller role in the economy, they transition from a rural to an urban manufacturing and service economy. These results suggest that China's agricultural policies are now similar to those of developed rather than developing countries. 
Besides economic growth in the non-agricultural sector as a driver of policy changes, commodity-specific factors are also important, including the degree of responsiveness of a sector to price incentives (the price elasticity of supply) and the size and dispersion of a particular agricultural commodity sector. China's admission into the World Trade Organization does not seem to have had a discernable impact on agricultural subsidy rates that could not be explained by other internal political-economic factors. This suggests that the explanation of changes in agricultural policy in China must include national, ideological, and political factors so that the determinants of subsidy rates can be better comprehended. In spite of recent fears about the future prospects of the Chinese economy, this article predicts that the level of subsidies will flatten out in the next decade and even decline slightly to levels more consistent with those of the United States and other developed countries. In spite of the increased levels of support to domestic farmers, even under the WTO, China will remain a potentially attractive market for countries exporting agricultural products, particularly animal products where subsidies are predicted to remain at lower levels than the ones targeting crop farmers, except for crops that have become prominent in the agro-industrial complex for feed and processed foods. 
Figure 1. Trends in Production and Consumption of Livestock Products
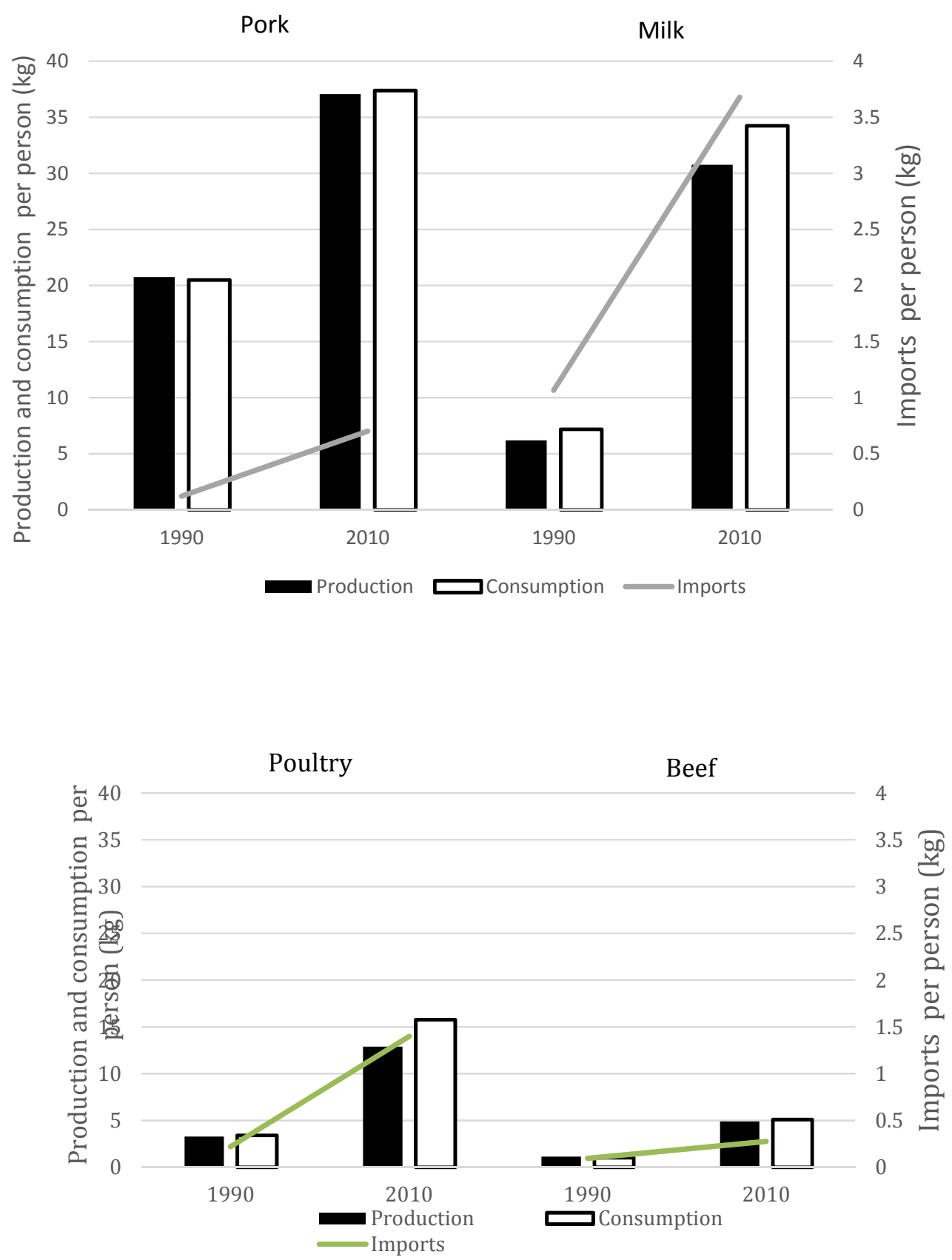

Source: FAO (2015). Milk includes all dairy products except butter. 
Figure 2. Trends in Production and Consumption of Crops
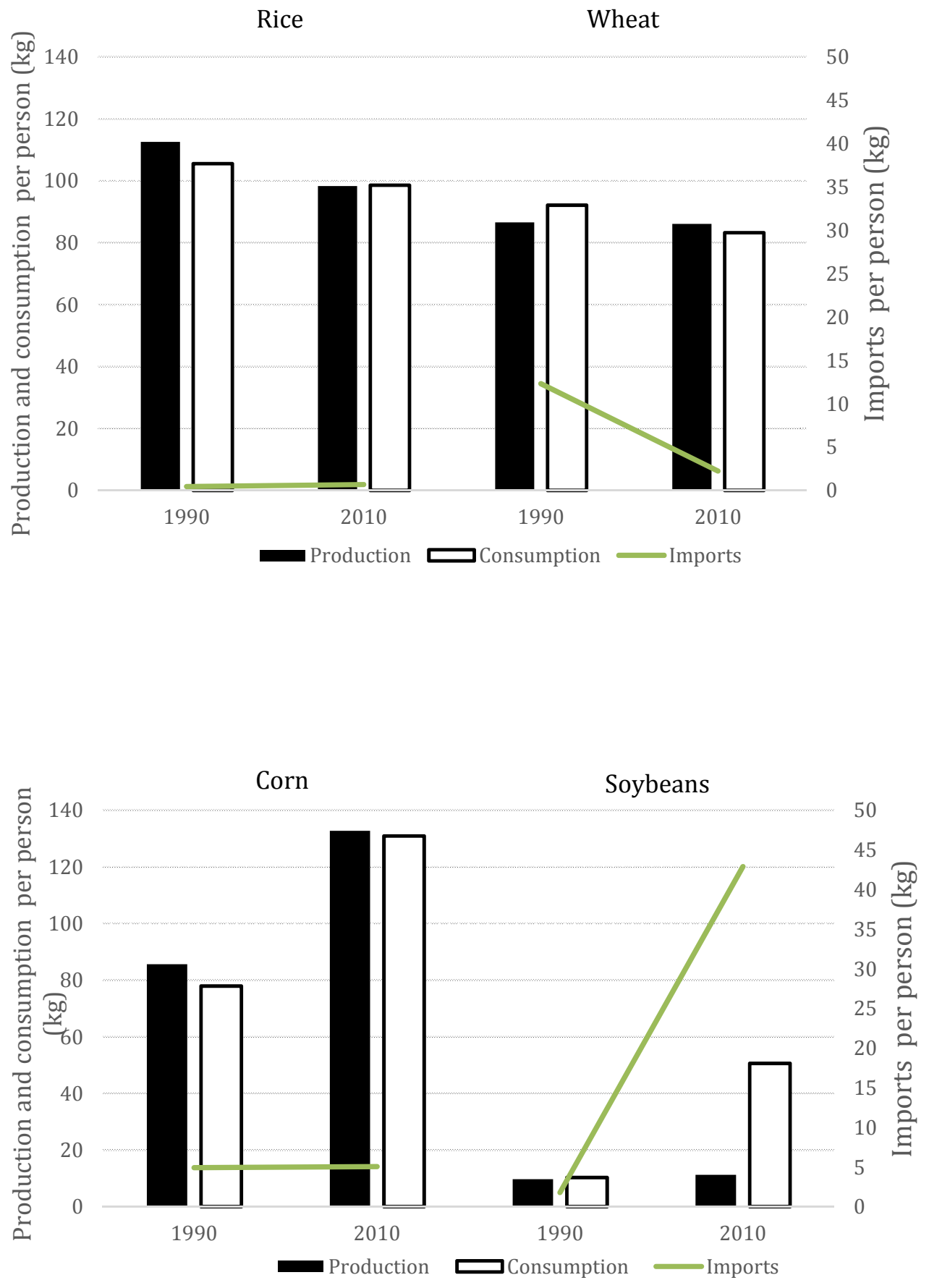

Source: FAO (2015). Rice is expressed in millet equivalents. 
Figure 3: PSEs by Sources of Funding: Output v. Input Subsidies, 1984-2012

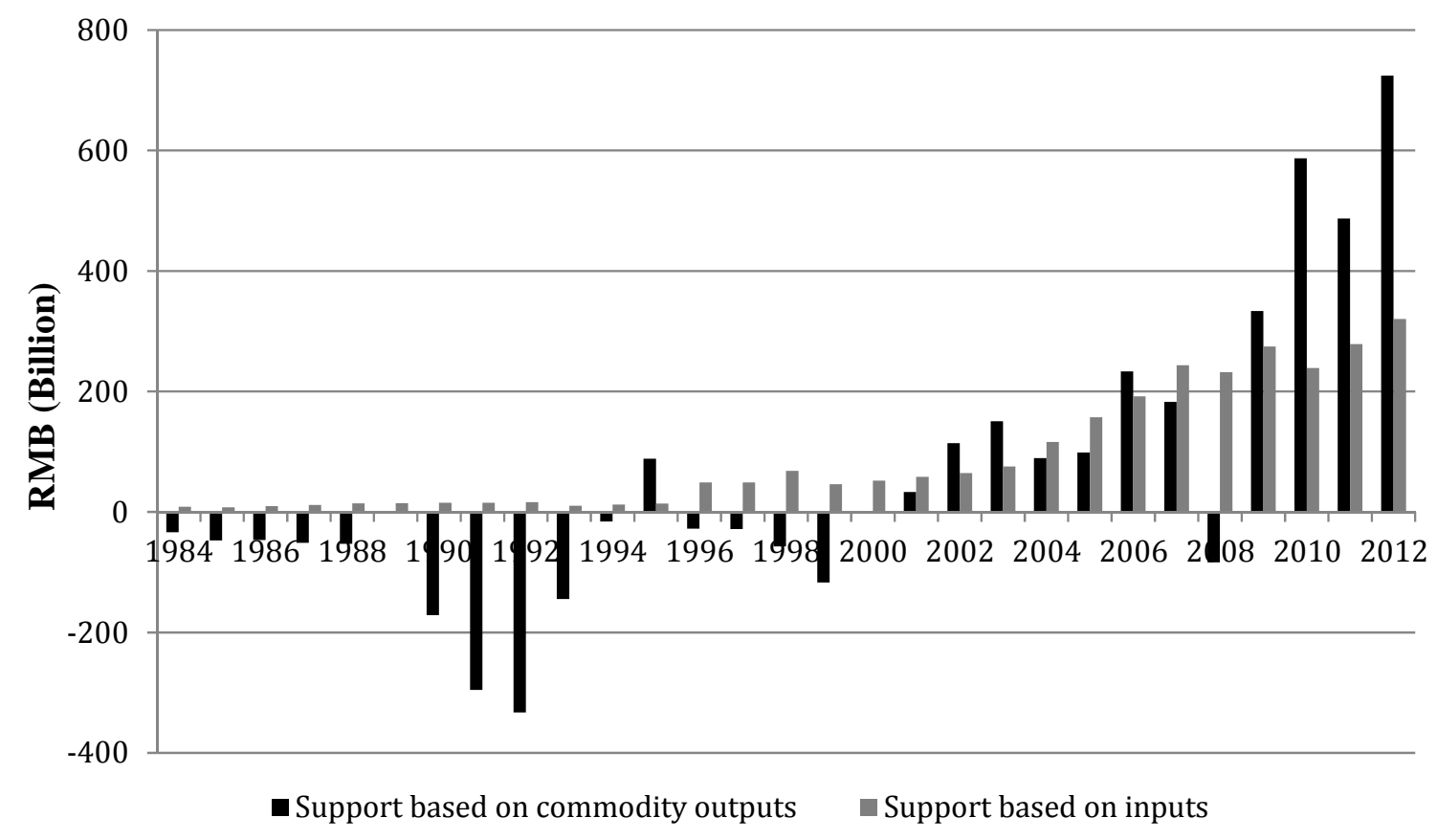

Source: from 1984 to 1993: USDA, from 1994 to 2012: OECD.

Note: The 16 agricultural commodities include apples, corn, cotton, peanuts, rapeseed, rice, soybeans, sugar, wheat, beef, eggs, honey, milk, pork, poultry and lamb. 
Figure 4: PSEs by Commodity Types: Crops v. Livestock, 1984-2012

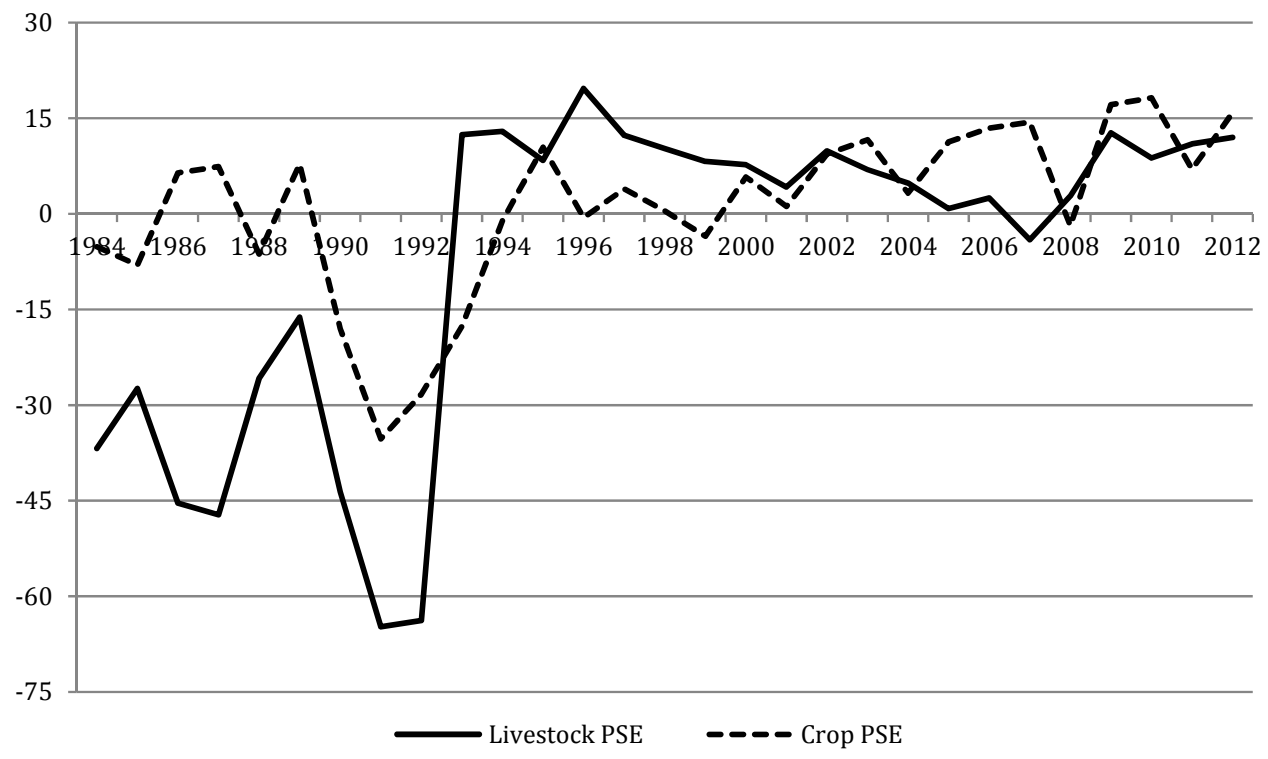

Note: Crops include apples, corn, cotton, peanuts, rapeseed, rice, soybeans, sugar, and wheat. Livestock commodities include beef, eggs, honey, milk, pork, poultry and lamb. 
Figure 5: Observed and Predicted PSE levels: 1984-2012

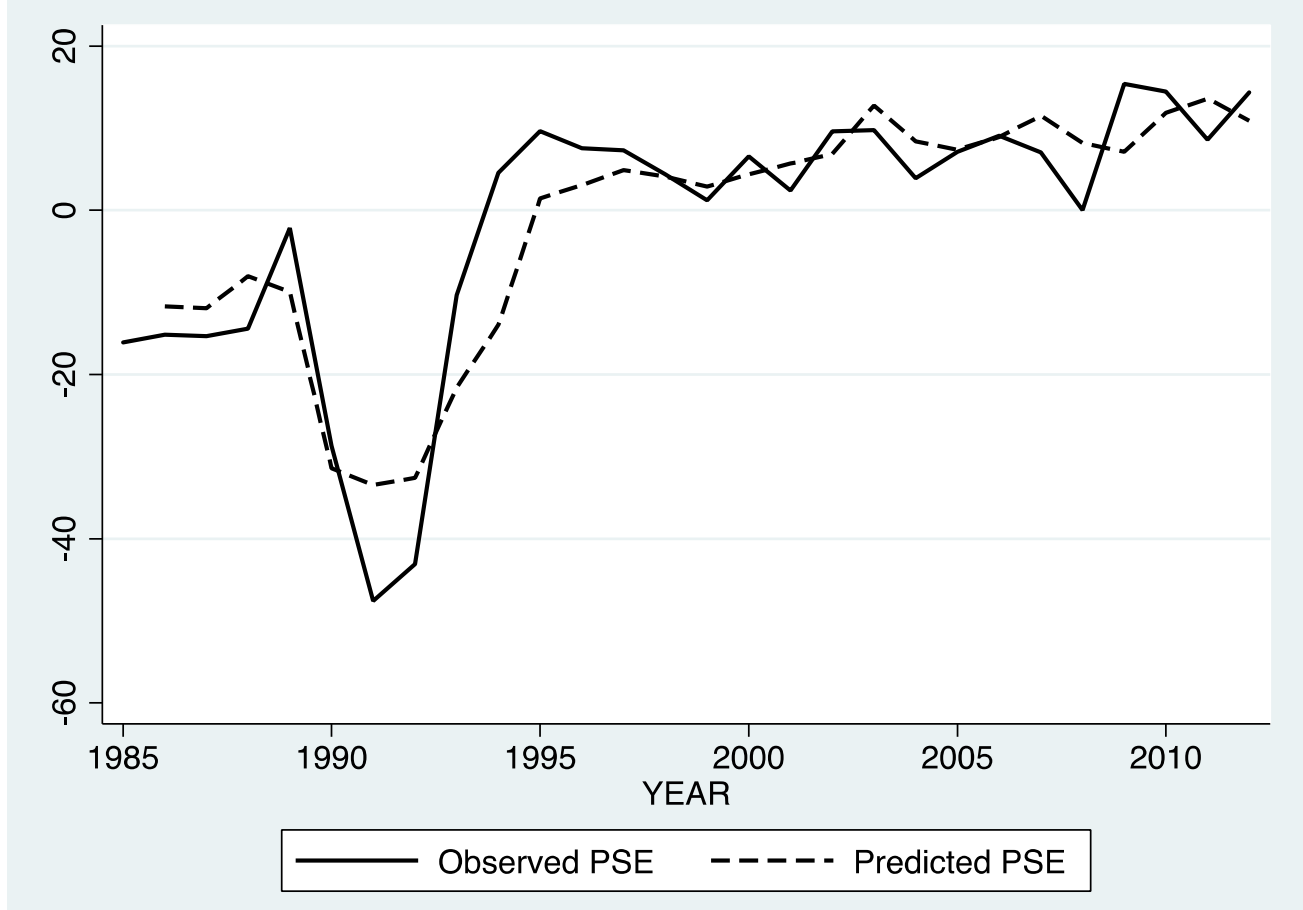

Sources: from 1984 to 1992: USDA (1994), from 1994 to 2012: OECD (2014b). 
Figure 6: Predicted PSEs for 2013 to 2022

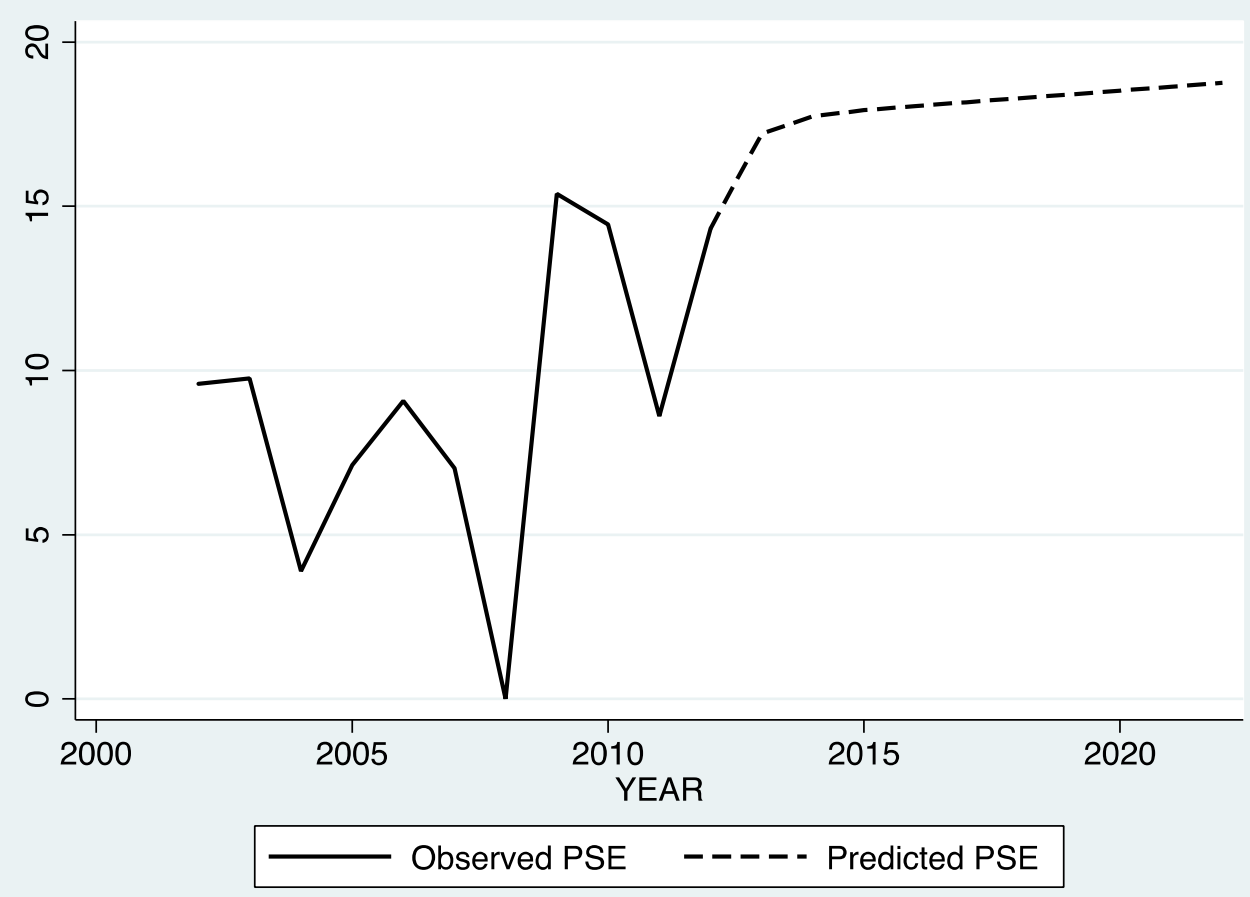


Figure 7: Predicted PSEs for Crops v. Livestock for 2013 to 2022

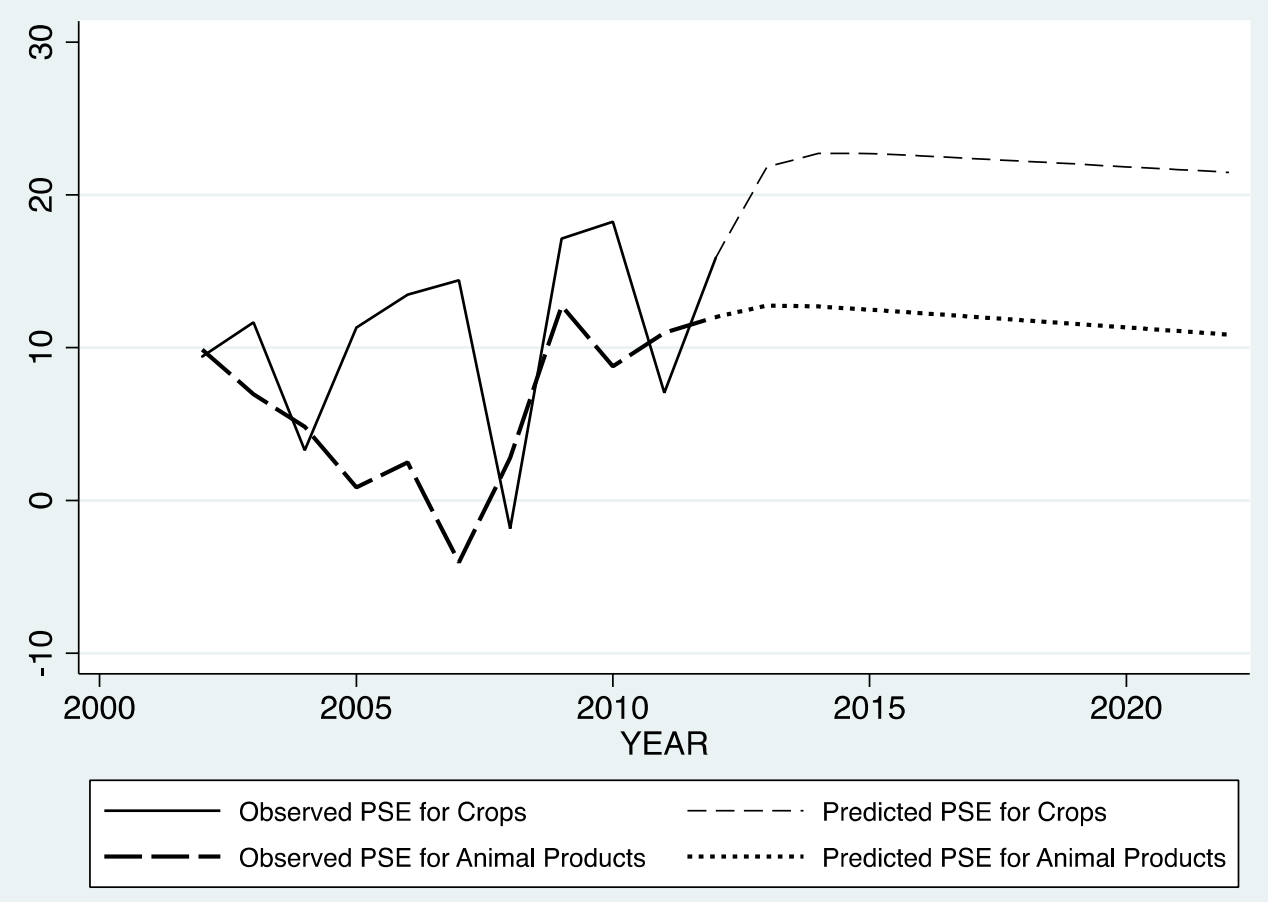


Table 1. Summary Statistics of Sample and Related Data

\begin{tabular}{lcccc}
\hline \hline & Period 1: & Period 2: & Period 3: & Period 4: \\
& 1984-1989 & $1990-1994$ & $1995-2001$ & $2002-2012$ \\
& Mean & Mean & Mean & Mean \\
\hline National-level variables & & & & \\
Real GDP Per Capita (RMB) & 1005.93 & 2346.65 & 6644.54 & 20518.56 \\
Agriculture Share of GDP & 0.27 & 0.21 & 0.17 & 0.1 \\
Urbanization rate & 0.25 & 0.28 & 0.33 & 0.46 \\
Transfers from consumers (Billion & & & -158.5 & 2652.2 \\
RMB) & 388.1 & -1920 & 480.6 & 1895.5 \\
Budget transfers (Billion RMB) & 11.4 & 137.7 & & \\
Commodity-specific variables & & & -541.1 & 11755.4 \\
PSE & -2188.5 & -12801.2 & 5.57 & 9.02 \\
Percent PSE & -13.58 & -21.94 & 0.11 & 0.15 \\
NRP & -0.11 & -0.13 & 8.06 & 15.67 \\
GEO* Production Value & 2.3 & 4.43 & 0.94 & 0.92 \\
Self-insufficiency & 2.27 & 1.41 & 33.64 & 40.26 \\
Production level (Thousand tons) & 28.23 & 31.11 & 88.4 & 172.3 \\
Production value (Billion RMB) & 25.7 & 49.3 & 35.04 & 42.41 \\
Consumption level (Thousand tons) & 28.35 & 30.85 & 91.8 & 187.3 \\
Consumption value (Billion RMB) & 20.5 & 48.8 & -0.31 & -0.34 \\
Demand elasticity w.r.t output price & -0.99 & -0.8 & 0.87 & 0.56 \\
Supply elasticity w.r.t output price & 0.45 & -1.51 & -1.32 \\
Supply elasticity w.r.t input price & -.84 & -105 & 165 \\
\hline Number of Observations & 72 & & & \\
\hline \hline
\end{tabular}

Note: 1978 is the baseline year. Real GDP per capita in China was 381 RMB in 1978. Note that the mean values for each period are the simple averages across commodities and years, not the weighted averages. 
Table 2: Estimated Demand and Supply Elasticities

\begin{tabular}{llccc}
\hline \hline No. & Commodity & $\begin{array}{c}\text { Demand } \\
\text { elasticity } \\
\left(\widehat{\eta_{\imath t}}\right)\end{array}$ & $\begin{array}{c}\text { Supply } \\
\text { elasticity } \\
\left(\widehat{\varepsilon_{J t}}\right)\end{array}$ & $\begin{array}{c}\text { Input supply } \\
\text { elasticity } \\
\left(\widehat{\beta_{J l t}}\right)\end{array}$ \\
\hline & Crops: & & & \\
1 & Apples & -0.3582 & 0.6290 & -4.3698 \\
2 & Corn & -0.1287 & 0.8240 & -0.0158 \\
3 & Cotton & -0.1370 & 0.3228 & -0.3561 \\
4 & Peanuts & -1.2737 & 0.3371 & -0.0601 \\
5 & Rapeseed & -1.5293 & 0.4223 & -1.1750 \\
6 & Rice & -0.1191 & 0.1095 & -0.0570 \\
7 & Soybeans & -0.2914 & 0.0051 & -2.1762 \\
8 & Sugar & -0.4507 & 0.1461 & -1.7631 \\
9 & Wheat & -0.0993 & 0.2212 & -0.6020 \\
& Livestock Products & & \\
10 & Beef & -0.7205 & 1.1683 & -2.7307 \\
11 & Eggs & -0.2859 & 1.4947 & -2.2591 \\
12 & Honey & -1.6185 & 0.0894 & -1.0761 \\
13 & Milk & -0.1459 & 4.4182 & -2.1472 \\
14 & Pork & -0.3764 & 0.1985 & -3.5788 \\
15 & Poultry & -0.7876 & 1.1947 & -4.5922 \\
16 & Lamb & -0.4005 & 0.0598 & -.45089 \\
\hline \hline
\end{tabular}

Note: For estimation details see the appendix. The values in the tables are the mean values. 
Table 3: Determinants of Producer Subsidies Equivalents in Chinese Agriculture

\begin{tabular}{|c|c|c|}
\hline & $\begin{array}{c}\text { Coefficient } \\
\text { (Standard error) }\end{array}$ & $\begin{array}{l}\text { Beta coefficient } \\
\text { (Standard error) }\end{array}$ \\
\hline \multicolumn{3}{|l|}{ National-level variables } \\
\hline Real GDP Per Capita & $\begin{array}{l}0.0012 * * * \\
(0.00)\end{array}$ & $\begin{array}{l}0.50 * * * \\
(0.15)\end{array}$ \\
\hline Agriculture share of GDP & $\begin{array}{l}-248.9 * * \\
(103.39)\end{array}$ & $\begin{array}{l}-0.64 * * \\
(0.26)\end{array}$ \\
\hline \multicolumn{3}{|c|}{ Commodity-specific variables } \\
\hline Supply elasticity & $\begin{array}{l}9.88 * * \\
(4.88)\end{array}$ & $\begin{array}{c}0.38^{*} \\
(0.21)\end{array}$ \\
\hline Demand elasticity & $\begin{array}{l}-0.79 \\
(2.31)\end{array}$ & $\begin{array}{l}-0.024 \\
(0.07)\end{array}$ \\
\hline Input supply elasticity & $\begin{array}{l}-2.91 \\
(4.07)\end{array}$ & $\begin{array}{l}-0.10 \\
(0.22)\end{array}$ \\
\hline GEO* Production Value & $\begin{array}{l}3.90 * * * \\
(1.46)\end{array}$ & $\begin{array}{l}0.22 * * * \\
(0.08)\end{array}$ \\
\hline Self-insufficiency & $\begin{array}{c}0.18 \\
(0.18)\end{array}$ & $\begin{array}{l}0.065 \\
(0.08)\end{array}$ \\
\hline \multicolumn{3}{|l|}{ Time period dummies } \\
\hline Urban Instability & $\begin{array}{l}-12.9 * * * \\
(2.65)\end{array}$ & $\begin{array}{l}-0.51 * * * \\
(0.11)\end{array}$ \\
\hline WTO & $\begin{array}{l}9.34 * * * \\
(2.67)\end{array}$ & $\begin{array}{l}0.37 * * * \\
(0.11)\end{array}$ \\
\hline Time trend & $\begin{array}{l}-4.24 * * * \\
(1.18)\end{array}$ & $\begin{array}{l}-0.17 * * * \\
(0.05)\end{array}$ \\
\hline OECD & $\begin{array}{l}30.8 * * * \\
(4.63)\end{array}$ & $\begin{array}{l}1.23^{* * *} \\
(0.19)\end{array}$ \\
\hline Lagged PSE & $\begin{array}{l}0.28 * * * \\
(0.05)\end{array}$ & $\begin{array}{l}0.28^{* * * *} \\
(0.05)\end{array}$ \\
\hline Commodity fixed effects & Yes & Yes \\
\hline $\mathrm{N}$ & 360 & 360 \\
\hline $\operatorname{AR}(1)$ & 0.000 & 0.000 \\
\hline $\operatorname{AR}(2)$ & 0.173 & 0.179 \\
\hline Sargan test & 0.359 & 0.235 \\
\hline
\end{tabular}

Note: One, two and three asterisks indicate significance levels at the 1,5 and $10 \%$, respectively. 
Table 4. Determinants of Nominal Rates of Protection in Chinese Agriculture

\begin{tabular}{|c|c|c|c|}
\hline \multirow{2}{*}{ National-level variables } & \multirow[t]{2}{*}{$\begin{array}{c}\text { Coefficient } \\
\text { (Standard error) }\end{array}$} & \multicolumn{2}{|c|}{$\begin{array}{l}\text { Beta coefficient } \\
\text { (Standard error) }\end{array}$} \\
\hline & & & \\
\hline \multirow[t]{2}{*}{ Real GDP Per Capita } & $0.000011 * *$ & & $0.37 * *$ \\
\hline & $(0.00)$ & & $(0.15)$ \\
\hline \multirow[t]{2}{*}{ Agriculture share of GDP } & -1.67 & & -0.35 \\
\hline & $(1.26)$ & & $(0.26)$ \\
\hline \multicolumn{4}{|c|}{ Commodity-specific variables } \\
\hline \multirow[t]{2}{*}{ Supply elasticity } & 0.091 & 0.30 & \\
\hline & $(0.06)$ & $(0.23)$ & \\
\hline \multirow[t]{2}{*}{ Demand elasticity } & -0.019 & -0.048 & \\
\hline & $(0.03)$ & $(0.07)$ & \\
\hline \multirow[t]{2}{*}{ Input supply elasticity } & 0.026 & 0.16 & \\
\hline & $(0.05)$ & $(0.23)$ & \\
\hline \multirow[t]{2}{*}{ GEO* Production Value } & 0.010 & 0.047 & \\
\hline & $(0.02)$ & $(0.08)$ & \\
\hline \multirow[t]{2}{*}{ Self-insufficiency } & -0.00026 & -0.016 & \\
\hline & $(0.00)$ & $(0.08)$ & \\
\hline \multicolumn{4}{|l|}{ Time period dummies } \\
\hline \multirow[t]{2}{*}{ Urban Instability } & $-0.099 * * *$ & & $-0.33 * * *$ \\
\hline & $(0.03)$ & & $(0.11)$ \\
\hline \multirow[t]{2}{*}{ WTO } & $0.12 * * *$ & & $0.39 * * *$ \\
\hline & $(0.03)$ & & $(0.11)$ \\
\hline \multirow[t]{2}{*}{ Time trend } & $-0.032 * *$ & & $-0.11 * *$ \\
\hline & $(0.01)$ & & $(0.05)$ \\
\hline \multirow[t]{2}{*}{ OECD Data } & $0.26^{* * *}$ & & $0.87 * * *$ \\
\hline & $(0.06)$ & & $(0.20)$ \\
\hline \multirow[t]{2}{*}{ Lagged NRP } & $0.24 * * *$ & & $0.24 * * *$ \\
\hline & $(0.05)$ & & $(0.05)$ \\
\hline Commodity fixed effects & Yes & & Yes \\
\hline $\mathrm{N}$ & 360 & & 360 \\
\hline $\operatorname{AR}(1)$ & 0.000 & & 0.000 \\
\hline $\operatorname{AR}(2)$ & 0.573 & & 0.559 \\
\hline Sargan test & 0.769 & & 0.718 \\
\hline
\end{tabular}

Note: One, two and three asterisks indicate significance levels at the 1, 5 and 10\%, respectively. 
Table 5. Results for Crops vs. Livestock Products

\begin{tabular}{|c|c|c|}
\hline & Crops & Livestock products \\
\hline \multicolumn{3}{|l|}{ National-level variables } \\
\hline \multirow[t]{2}{*}{ Real GDP Per Capita } & $0.42 * *$ & $0.53 * * *$ \\
\hline & $(0.21)$ & $(0.19)$ \\
\hline \multirow[t]{2}{*}{ Agriculture share of GDP } & $-0.61 *$ & $-0.85 * *$ \\
\hline & $(0.35)$ & $(0.35)$ \\
\hline \multicolumn{3}{|c|}{ Commodity-specific variables } \\
\hline \multirow[t]{2}{*}{ Supply elasticity } & -0.54 & $0.38 * * *$ \\
\hline & $(0.94)$ & $(0.12)$ \\
\hline \multirow[t]{2}{*}{ Demand elasticity } & -0.078 & -0.33 \\
\hline & $(0.06)$ & $(0.21)$ \\
\hline \multirow[t]{2}{*}{ Input supply elasticity } & $-0.37 *$ & 0.083 \\
\hline & $(0.21)$ & $(0.11)$ \\
\hline \multirow[t]{2}{*}{ HHI*production value } & 0.20 & -0.010 \\
\hline & $(0.18)$ & $(0.09)$ \\
\hline \multirow[t]{2}{*}{ Self-insufficiency } & 0.022 & $-1.08^{*}$ \\
\hline & $(0.09)$ & $(0.55)$ \\
\hline \multicolumn{3}{|l|}{ Time period dummies } \\
\hline \multirow[t]{2}{*}{ Urban Instability } & $-0.63 * * *$ & $-0.32 * *$ \\
\hline & $(0.14)$ & $(0.14)$ \\
\hline \multirow[t]{2}{*}{ WTO } & $0.57 * * *$ & 0.14 \\
\hline & $(0.15)$ & $(0.14)$ \\
\hline \multirow[t]{2}{*}{ Time trend } & $-0.17 * * *$ & $-0.20 * * *$ \\
\hline & $(0.06)$ & $(0.06)$ \\
\hline \multirow[t]{2}{*}{ OECD Data } & $0.70 * *$ & $2.11 * * *$ \\
\hline & $(0.27)$ & $(0.25)$ \\
\hline \multirow[t]{2}{*}{ Lagged PSE } & $0.27 * * *$ & $0.24 * * *$ \\
\hline & $(0.06)$ & $(0.07)$ \\
\hline $\mathrm{N}$ & 216 & 144 \\
\hline
\end{tabular}

Note: One, two and three asterisks indicate significance levels at the 1, 5 and $10 \%$, respectively. 


\section{References}

Arellano, M. \& S.R. Bond. (1991). Some tests of specification for panel data: Monte Carlo evidence and an application to employment equations. Review of Economic Studies, 58(2), $277-297$.

Arellano, M. \& O. Bover. (1995). Another look at the instrumental variable estimation of errorcomponents models. Journal of Econometrics, 68(1), 29-51.

Beghin, J. C. \& M. Kherallah. (1994). Political institutions and international patterns of agricultural protection. The Review of Economics and Statistics, 76(3), 482-489.

Blundell, R., \& S. Bond. (1998). Initial conditions and moment restrictions in dynamic panel data models. Journal of Econometrics, 87(1), 115-143.

Blundell R.W. \& S.R. Bond. (2000). GMM estimation with persistent panel data: An application to production functions. Econometric Reviews, 19, 321-340

Carter, C. A. et al. (2002). "Introduction," in China's Food and Agriculture: Issues for the 21th Century. Fred Gale, editor, Market and Trade Economics Division, Economic Research Service, U.S. Department of Agriculture. Agriculture Information Bulletin No. 775. Available online at: http://www.ers.usda.gov/publications/aib-agriculturalinformationbulletin/aib775.aspx\#.U21Wi_1_tO0

Carter, C. A. \& S. Rozelle. (2002). "Will China's agricultural trade reflect its comparative advantage?" in China's Food and Agriculture: Issues for the 21th Century. Fred Gale, editor, Market and Trade Economics Division, Economic Research Service, U.S. Department of Agriculture. Agriculture Information Bulletin No. 775. 
Fang, C., F. Tuan, \& F. Zhong. (2002). "How might China protect its agricultural sector?” in China's Food and Agriculture: Issues for the 21th Century. Fred Gale, editor, Market and Trade Economics Division, Economic Research Service, U.S. Department of Agriculture. Agriculture Information Bulletin No. 775.

Food and Agriculture Organization of the United Nations (FAO). (2015). FAOSTAT Agricultural Data. Accessed online from: http:/faostat3.fao.org/faostatgateway/go/to/download/FB/*/E

Fuller, F., Hayes, D., and D. Smith. (2000). Reconciling Chinese meat production and consumption data, Economic Development and Cultural Change, 49(1): 23-43.

Gardner, B. L. (1987). Causes of US farm commodity programs. Journal of Political Economy, 95(2), 290-310.

Gawande, K. \& B. Hoekman. (2006). Lobbying and agricultural trade policy in the United States. International Organization, 60(3), 527-561.

Honma, M. \& Y. Hayami. (1986). Structure of agricultural protection in industrial countries. Journal of International Economics, 20(1), 115-129.

Huang, J., S. Rozelle, and M. Rosegrant. (1998). China's food economy to the 21 st Century: supply, demand and trade. Economic Development and Cultural Change, 47(4): 737-766.

Huang, J., X. Wang, \& S. Rozelle. (2013). The subsidization of farming households in China's agriculture. Food Policy, 41, 124-132.

International Monetary Fund. (2015). Word Economic Outlook Database. Available online at: http://www.imf.org/external/pubs/ft/weo/2015/01/weodata/index.aspx 
Klomp, J. \& J. de Haan. (2013). Conditional election and partisan cycles in government support to the agricultural sector: An empirical analysis. American Journal of Agricultural Economics, 95, 793-818.

Knutson, R. D., Penn, J. B., Flinchbaugh, B. L., \& Outlaw, J. L. (2007). Agricultural and food policy. Pearson/Prentice Hall.

Lin, J. Y. (1990). Collectivization and China's agricultural crisis in 1959-1961. Journal of Political Economy, 1228-1252.

Lopez, Rigoberto A. (2001). Campaign contributions and agricultural subsidies. Economics and Politics, 13 (November), 257-279.

Lopez, R. \& I. Hathie. (2000). The structure of government intervention in African agriculture. Journal of Development Studies, 37(1), 57-72.

Ma, H., A. Rae, J. Huang, and S. Rozelle. (2004). Chinese animal product consumption in the 1990s. Australian Journal of Agricultural and Resource Economics, 48(4): 569-590.

Magee, S.P., W.A. Brock, and L. Young. (1989). Black Hole Tariffs and Endogenous Policy Theory. Cambridge, U.K.: Cambridge University Press.

National Bureau of Statistics of China. (1995-2013a). China Statistical Yearbook. China Statistics Press, Beijing, People's Republic of China.

National Bureau of Statistics of China (1995-2013b). China Rural Statistical Yearbook. China Statistics Press, Beijing, People's Republic of China. 
Organization for Economic Cooperation and Development (OECD). (2014a). Economic

Outlook No. 95-May 2015-Long term baseline projections. Available online at:

http://stats.oecd.org/Index.aspx?DataSetCode=EO95 LTB\#

Organization for Economic Cooperation and Development (OECD). (2014b) Producer and Consumer Support Estimates Database. Accessed April 4, 2015 from: http://www.oecd.org/tad/agricultural-

policies/producerandconsumersupportestimatesdatabase.htm

Party History Research Center of the CPC Central Committee of China, (2011)._History of the Communist Party of China. Party History Press, Beijing, China.

Roodman, D. (2009). How to do xtabond2: An introduction to difference and system GMM in Stata. Stata Journal, 9(1), 86-136.

U.S. Department of Agriculture (1994). Estimates of Producer and Consumer Subsidy Equivalents:

Government Intervention in Agriculture, 1982-92. Economic Research Service, Statistical Bulletin 913, Washington, D.C.

U.S. Department of Agriculture (2006). Commodities and Food Elasticities. Accessed May 15, 2015 , from http://www.ers.usda.gov/data-products/commodity-and-food-elasticities/demandelasticities-from-literature.aspx).

U.S. Department of Agriculture (2012). China Agriculture and Economic Data. Accessed Jan 19 , 
from http://www.ers.usda.gov/data-products/china-agricultural-and-economicdata/national-and-provincial-data.aspx).

Wang, X. \& Y. Shen. (2014). The effect of China's agricultural tax abolition on rural families' incomes and production. China Economic Review, 29, 185-199.

Westcott, P. \& R. Trostle. (2013). USDA Agricultural Projections to 2022, Economic Research Service. Accessed from http://www.ers.usda.gov/publications/oce-usda-agricultural-projections/oce131.aspx

World Bank. (2015). China Overview. Accessed from http://www.worldbank.org/en/country/china/overview

Xiao, Guo'an. 2005. An economic approach to the direct subsidization policy for grains in China, Chinese Rural Economy 3,12-17.

Yu, W. \& H. G. Jensen. (2010). China's agricultural policy transition: Impacts of recent reforms and future scenarios. Journal of Agricultural Economics, 61(2), 343-368.

Zheng, S., D.M. Lambert, S. Wang, \& Z. Wang. (2013). Effects of agricultural subsidy policies on comparative advantage and production protection in China: An application with a policy analysis matrix model. The Chinese Economy, 46(1), 20-37.

Zhou, Z. and W. Tian. (2003). China's regional feed Grain markets: developments and prospects. Report for Grains Research and Development Corporation, University of Sidney, Australia.

Zhou, Z., Tian, W., Wang, J., Liu, H., and L. Cao. (2012). Food consumption trends in China, April 2012, Report submitted to Australian Government Department of Agriculture, 
$\begin{array}{llll}\text { Fisheries } & \text { Forestry. } & \text { Accessed } & \text { from }\end{array}$ http://www.daff.gov.au/_ data/assets/pdf file/0006/2259123/food-consumption-trends$\underline{\text { in-china-v2.pdf }}$ 